\title{
An Economist's Guide to the Industrial Relations Reform Act
}

\author{
Judith Sloan
}

$\mathbf{M}$ ost economists despair when they consider the complex and obscure industrial-relations (IR) arrangements that apply in Australia. Conversely, many of those who follow the details of IR regulations and institutions in Australia know little about economics. This chasm has unfortunate consequences. Economists tend to support more rapid IR reform, yet often have little idea about how change might actually proceed from the present institutional starting point. More damaging are the recommendations for IR changes that are uninformed by any understanding of their economic effects.

The re-election of the Labor government at the 1993 federal election had profound implications for the direction of industrial-relations reform. Whereas the Liberal-National Coalition had been advocating an effective transformation of IR arrangements through the phased abolition of compulsory arbitration and its replacement by enterprise bargaining, ALP policy involved only marginal change. Commentators were therefore taken by surprise by Prime Minister Keating's first major speech after the election, when he spelt out an IR reform agenda that had much in common with the Coalition's policy. He spoke of the primacy of bargaining over awards; of agreements becoming more than add-ons to awards; of the need for awards to become simpler; and of the need to open up bargaining to nonunionised enterprises. At the same time, he foreshadowed a legislated 'right to strike' and the use of Australia's signature to International Labour Organisation (II.O) Conventions to guarantee minimum entitlements to all workers.

As the year wore on, however, it became increasingly clear that the Labor government would not deliver real labour-market reform because of the binding constraint of its relationship with the union movement. What eventually emerged was a piece of legislation, the Industrial Relations Reform Act 1993, which paid lip-service to the rhetoric - 'flexibility with protection' - yet which involved complex and convoluted extensions of the centralised IR system combined with a highly regulated bargaining stream.

Judith Sloan is Director of the National Institute for Labour Studies at the Flinders University of South Australia. 


\section{An Overview of the Industrial Relations Reform Act 1993}

The Industrial Relations Reform Act 1993 is an extremely complex document of over 200 pages. To operate in conjunction with (and amending parts of) the Industrial Relations Act 1988, it provides for highly detailed and transcending regulation of almost every aspect of industrial relations. ${ }^{1}$ The Act is divided into six parts. Some of the key changes include: new objects for the Act; the spelling out of the role of the award system and rules for award variation; a range of minimum entitlements; the promotion of bargaining and facilitation of agreements; and new provisions governing secondary boycotts.

The objects of the new Act emphasise the prevention and settlement of disputes through conciliation and the making of agreements. But the arbitral option is retained. In addition, an object of the Act is to provide the means for 'establishing and maintaining an effective framework for protecting wages and conditions of employment through awards' and 'ensuring that labour standards meet Australia's international obligations' (p.2). A further object is to 'prevent and eliminate discrimination on the basis of race, colour, sex, sexual preference, age, physical or mental disability, marital status, family responsibilities, pregnancy, religion, political opinion, national extraction or social origin' (p.3).

Part 3 outlines the award system. Awards are seen 'as a safety net of minimum wages and conditions of employment underpinning direct bargaining' (p.3). The Industrial Relations Commission (IRC) is instructed to ensure that 'the system of awards provides for secure, relevant and consistent wages and conditions of employment' (p.4).

In Part 4, a number of minimum entitlements of employees guaranteed by the Act are detailed. Resorting to the External Affairs power of the Constitution and Australia's signature to a number of international conventions, the Act establishes minimum entitlements in five main areas: minimum wages, equal remuneration for work of equal value, termination of employment, parental leave, and leave to care for immediate family. Of the five categories, the most radical changes from previous practice relate to termination of employment. Employers are now required to prove both substantive and procedural fairness when dismissing employees. Employees who have, in their opinion, had their employment unfairly terminated can apply to the new Industrial Relations Court (which takes over the industrial-relations functions of the Federal Court) for re-instatement and compensation, although the Commission may conciliate on the matter.

Part 5 deals with 'Promoting Bargaining and Facilitating Agreements'. Use is made of the Corporations power in the Constitution, in addition to the Conciliation and Arbitration power. As a result, the strict interstate test for an industrial dispute

\footnotetext{
${ }^{1}$ It is ironic, given the government's intention to promote enterprise bargaining, that the current legislative framework is now more prescriptive and regulatory in substance than the Industrial Relations Act 1988. Under this latter Act, over-award bargaining was essentially unregulated.
} 
becomes unnecessary to trigger the involvement of the IRC. Moreover, the new concept of an 'industrial situation' is introduced in the Act, which allows the Commission to become involved to prevent an industrial dispute occurring. In addition, the legislation stipulates a definition of 'enterprise' that refers to a single employer or business with workplaces at different geographical sites. The importance of this definition is the implied preclusion of individual contracting and agreements that apply to only a portion of an enterprise's workforce.

There are two routes by which enterprise agreements can be ratified by the IRC and thereby override awards (where an agreement is silent on a matter, the award provision applies.) The first route is that of Certified Agreements, which can be made only with a registered union or unions as parties. The provisions governing the making and ratification of Certified Agreements are highly prescriptive and involve the satisfying of a 'no disadvantage' test, which states that workers must be no worse off on balance under such agreements than under award conditions. ${ }^{2}$

The second route is that of Enterprise Flexibility Agreements, which is ostensibly the means of ratifying non-union agreements made directly with workers. Again, the provisions are highly prescriptive and indeed involve steps in addition to those required for Certified Agreements. Where any union members are on-site, an employer is required to notify the relevant union or unions of impending negotiations. The union or unions may then elect to become a party to the negotiations. Where there are no union members, the relevant union or unions have the right to intervene prior to the IRC ratifying the agreement, although they have no veto power. The IRC may refuse to ratify an Enterprise Flexibility Agreement if it deems it not to be in the 'public interest', although this test does not refer to compliance with IRC principles. One of the many tests that an Enterprise Flexibility Agreement must pass before being ratified is that a majority of the workforce must favour the agreement.

Under the Act, the Commission is to be restructured into a Bargaining Division and the traditional award stream. The main function of the Bargaining Division is to oversee bargaining and ratify agreements, as well as handling Paid Rates Awards, which latter cover public servants and are important in a number of industries. Arguably, the Vice-President of the Bargaining Division holds the most powerful position in the Commission. One of the functions of the Bargaining Division is to supervise 'bargaining periods' while agreements are being negotiated, during which an immunity from civil liability applies to industrial disputes. In other words, a 'right to strike' is introduced by this Act. There is a 'bargaining in good faith' provision within the Act that unions can use to force employers to the negotiating table, although they are not obliged to make any concessions or to reach agreement.

Finally, Part 7 contains provisions related to secondary boycotts, which have been repositioned and significantly reworded from the Trade Practices Act. The definition of a secondary boycott is tightened in the Act to exclude a range of activi-

\footnotetext{
2 Note that greenfields enterprises cannot enter directly into an agreement with the workers. A necessary first step is the granting of an interim award against which 'no disadvantage' can be gauged.
} 
ties, including peaceful picketing and industrial action undertaken in the name of an industry campaign. A period of 72 hours of compulsory conciliation becomes mandatory.

\section{The Economics of the Industrial Relations Reform Act}

The process of policy formation that led to the Industrial Relations Reform Act has everything to do with politics and the relationship between the political and industrial wings of the labour movement, but virtually nothing to do with economics. This is so despite the speech made by the Prime Minister in April 1993, which related the need for further labour-market reform to the requirements of a globalised economy. What eventually emerged had little connection with microeconomic reform because of the need to produce an overwhelmingly pro-union package.

Perhaps the most favourable economic interpretation that can be placed on the Act is that, in the context of a recovering economy, the damage to business may only be marginal. Moreover, there is some scope within the legislation for the Commission to use its discretion in certain ways - to vary awards reluctantly or to reject vexatious objections from unions about Enterprise Flexibility Agreements, for instance - that may alter the direction of the labour-market reform process. ${ }^{3}$

A less favourable, but probably more realistic, interpretation of the Act is that it retards the process of labour-market decentralisation and reform that is required to enable Australia to compete effectively in the world economy. Rather than provide a simple and streamlined framework for enterprise bargaining that allows the parties to agree to establish wages and working arrangements that suit their circumstances, the Act over-regulates bargaining while simultaneously retaining and codifying centralised awards. The following sections consider the economic effects of a number of specific aspects of the legislation.

\section{The Award System}

The significance of the new Part 3 ('The Award System') is that it entrenches awards, explicitly states that awards will underpin enterprise bargaining, and stipulates the basis on which awards will be varied. However, awards are not suited to perform a safety-net function. Mainly configured along occupational lines flowing on from union respondency, the implied bargaining structure of awards cuts across enterprise lines. Most larger enterprises are covered by several awards, so in effect there are several safety nets underpinning agreements. When it comes to agreements, the Act is firmly prescriptive that all workers in an enterprise must be covered, even though in many instances workers are covered by different awards. Moreover, employer respondency to awards is not removed when enterprise agreements are made (as is the case under the new West Australian legislation, for

${ }^{3}$ In the light of the appointments to the Commission, including that of Iain Ross, former Assistant Secretary of the ACTU, to the position of Vice-President of the Bargaining Division, it seems highly unlikely that the Commission will use its discretion in these ways. 
example). As a consequence, employers are made to comply with several instruments, with agreement provisions overriding award clauses only where inconsistencies occur.

Apart from these regulatory arrangements that all but guarantee that agreements are mere add-ons to awards (many agreements already are only partial documents to be read in conjunction with relevant awards), most awards are detailed and prescriptive instruments setting out the terms of the individual employment contract and restricting the collective aspects of employment arrangements. Examples of the latter include restrictions on the use of part-time or casual workers and demarcation lines. In other words, awards are not simple statements of minimum entitlements that can be described as safety nets. Indeed, if the legislators simply wished to deliver on their rhetoric - 'flexibility with protection' - the range of minimum entitlements set down in the Act is surely sufficient to provide the protection, and to act as a safety net for enterprise bargaining.

This implies that the inclusion and wording of Part 3 have less to do with the protection of workers than with other considerations. One such consideration is the trade union movement's support for a hybrid arrangement, with continuing awards bolstered by (over-award) bargaining - a case of having the best of both worlds. A second, more cynical, consideration is the protection of union recognition and representation rights implied by awards. With few exceptions, most awards have only one union respondent. Since awards can be imposed on employers by arbitration, employers are forced to accept the representational role of the relevant union even if no employees belong to it. A third, and again cynical, consideration is the union movement's ambivalent attitude to enterprise bargaining, which may require substantial effort and resources. Seeking award variation from the Commission to apply to large numbers of employers is much less costly. It is even easier where award variation can be justified to the Commission on the basis of variations of other awards.

It is here that the adjectives 'secure, relevant and consistent', given prominence in this part of the Act, are so important. Market rates of pay (set by enterprise agreements) are likely to set the basis for relevance, and the relationship between rates of pay for key classifications across awards is likely to be achieved through flow-on award variations to ensure consistency. In other words, comparative wage justice is alive and well in this Act. (It is true that flow-ons are not strictly automatic but depend on the interpretation of the words 'secure, relevant and consistent'. Some limitation on them could come from an emphasis on conciliation over arbitration, that is, the making of agreements over the variation of awards.)

A number of economic arguments can be made against institutionalised comparative wage justice. First, it runs counter to the micro-level flexibility that might otherwise be expected to accompany true enterprise bargaining. That is, decentralised agreement-making should guarantee responsiveness between the actual circumstances of an enterprise and the contents of the employment contracts of employees. But comparative wage justice drives a high degree of uniformity of outcomes across occupations and industries. 
Second, a potentially dangerous upward bias is imparted to wage movements by the provisions in this part of the Act, as well as those contained elsewhere. By dint of the 'no disadvantage' rule that applies to agreement-making, both Certified Agreements and Enterprise Flexibility Agreements must, on balance, be at least as favourable to workers as award conditions. Moreover, as long as the other conditions attached to the making of agreements are met, there are no grounds for the Commission to refuse ratification. To the extent that agreements are used to establish relevance as the basis for award variation, the only direction for wage movements is up. With consistency of awards laid down as another criterion, the variation of one key award could easily trigger the rapid variation of a large number of other awards.

Such a situation is inferior to the admittedly second-best modus operandi that developed in the $1980 \mathrm{~s}$, with the Commission promulgating wage-fixing principles governing award variations and using the devices of a 'public interest' test and the extraction of 'no extra claims' commitments from the unions. In these ways, there was some control over nominal wage movements (Sloan, 1993). These options have been completely scuttled by the new Act, leaving the responsibility for wage moderation in the hands of the union movement and possibly restrictive macroeconomic settings.

In fact, the legislation has removed the Commission's discretion to establish its own principles to apply to award variations, including insistence on productivity trade-offs. In essence, the Act codifies the principles that will apply to awards and award variation, principles that are completely consistent with the union movement's agenda developed since the days of award restructuring. Key elements are skills-based career paths and consistent minimum rates of pay across awards.

It should also be noted that the union movement's agenda in this area is intimately connected with its preferred direction of reform in the training area. Thus the Carmichael Report's vision of an Australia-wide skills classification where all workers are grouped into a small number of skill levels (eight in all) will continue to spill into industrial relations, with rates of pay in awards increasingly set on the basis of these skill levels. Again it is a far cry from the flexible, decentralised IR arrangements that were expected to result from enterprise bargaining.

Indeed, the straight-jacket around wages and wage flexibility implied by these new developments make previous arrangements look quite flexible. These developments also raise a serious problem for employers: attainment versus application. Will employers be required to pay workers on the basis of the skill level they have attained or the skill content of the tasks they actually perform? At this stage the answer is unknown, but there are very clear economic consequences one way or the other.

\section{Minimum Wages}

An extremely important aspect of the new Act is the use of the External Affairs power of the Constitution to establish a range of minimum entitlements for all 
workers, including non-award workers, ostensibly to comply with a number of ILO Conventions and other international agreements to which Australia is signatory. In this way, the jurisdictional authority of the States is significantly undercut and the influence of the federal legislation is greatly enhanced. It is not clear that Australia has been contravening international conventions and agreements. The critical aspect of Part 4 of the Industrial Relations Reform Act is the interpretations placed on minimum entitlements.

Take, for instance, minimum wages. In most countries, compliance with the ILO Convention on this matter is achieved by the legislature stipulating a minimum hourly wage to apply to all workers. This route was also open to the federal government, since it based the Act on the External Affairs power of the Constitution as well as on the Corporations and the Conciliation and Arbitration powers. However, the government instead opted to interpret compliance by reference to minimum rates of pay as laid down in awards. As a result there is a multitude of minimum wages, which by no means apply only to low-paid workers.

It is not necessary here to traverse the economic arguments about the harmful effects of minimum wages on employment, particularly the employment prospects of workers with the lowest productivity. The point is that while these potentially harmful effects are entrenched in the system, the interpretation placed on minimum wages means that the legislation in respect of minimum wages cannot be defended on the normal grounds of protecting low-paid workers. An illustration of this anomalous situation is the $\$ 8$-a-week pay rise that began to flow from December 1993. Some very highly paid workers, in the banks for instance, were entitled to this pay rise as they received only minimum rates of pay - of over $\$ 1,000$ a week.

\section{Employment Termination}

As noted above, one of the most radical departures in the new Act is the section on termination of employment. The Act deals with three basic categories of employment termination: termination initiated by the employer for good reason; termination resulting from redundancy; and unfair dismissal. It sets down minimum periods of notice according to years of service. In the case of redundancies, employers are required to consult with unions and to notify the Commonwealth Employment Service where the number of redundancies is 15 or more.

Within 14 days of dismissal, any employee or trade union can apply to the new Industrial Relations Court for a remedy in respect of termination. To defend a charge of unfairly dismissing an employee, employers are required to prove both substantive and procedural fairness. The Court may refer the matter to the Commission for conciliation. However, the Court is empowered to order reinstatement and/or compensation.

The significance of these provisions is that whereas previously only award workers could seek industrial remedies for alleged unfair dismissal, now a larger proportion of workers may do so. As well, the compensation for dismissed em- 
ployees could be very generous. In other words, the legislation increases, perhaps markedly, the costs to employers of dismissing workers.

However, under proposed amendments to the Act announced on $30 \mathrm{May}$, compensation will be limited to six months' salary for award employees. In addition, non-award employees will have access to the unfair-dismissal provisions only if they earn less than $\$ 60,000$ annually, with compensation limited to $\$ 30,000$. Nevertheless, it is ironic that Australia should be heading in this direction precisely at the same time as several European countries are questioning their strong statute-based employment protection laws. The countries with the strongest laws in this area Spain, Greece and Italy - are those that face both the highest rates of unemployment and the most intractable structural unemployment problems (CEC, 1993). Where dismissal is made difficult and/or costly, firms become reluctant to take on workers. Moreover, the power of the 'insiders' (the employed) in the labour market is enhanced by employment-protection law. The ability of 'outsiders' (the unemployed) to compete with the 'insiders' becomes extremely limited (hence the structural nature of the unemployment problem) and the rate of unemployment at which wage pressures emerge is markedly increased.

It can be further argued that strong employment protection laws work against the interests of the most disadvantaged in the labour market. If a worker taken on is potentially a worker for life, employers are likely to adopt very cautious recruitment practices and recruit only workers who look like safe bets. Those who have been out of work for a long time are unlikely to be suitable, even though employing them might attract significant government subsidies. Like minimum wages, employment protection laws are ostensibly designed to protect workers but actually damage the prospects of the most disadvantaged.

\section{Non-discrimination}

One of the new Objects of the Act is to 'prevent and eliminate discrimination on the basis of race, colour, sex, sexual preference, age, physical or mental disability, marital status, family responsibilities, pregnancy, religion, political opinion, national extraction or social origin' (p.3). A number of the factors now mentioned in the Act were included in the very final amendments made to the legislation as it passed through the Senate.

On the face of it, these sorts of non-discrimination factors sound laudable enough and, in any case, innocuous. Yet this new Object raises a host of problems, particularly by referring to age. For example, junior rates of pay exist in very many awards, and explicitly or implicitly, in a number of agreements. Does this new $\mathrm{Ob}$ ject of the Act mean that junior rates of pay will no longer be allowable, because they imply discrimination on the basis of age?

The economics of junior rates of pay are very straightforward. If pay is set on the basis of age, the time path of pay can track increasing skill attainment. Junior rates of pay broadly impose the cost of general training on workers and an appropriate sharing of specific skill acquisition between firm and workers. Since age acts 
as a cheap proxy for increasing competence, there are strong economic grounds for retaining junior rates of pay. Other methods of assessing competence carry high transactions costs and generate approximately equal results in any case.

Another important aspect of non-discrimination on the basis of age is the implication for mandatory retirement. Again the economics are straightforward. If average productivity declines around retirement age, it is efficient to impose a simple rule whereby all individuals are required to retire at a set age. Obviously, some individuals could continue to work quite effectively after the age. But if on average the rule predicts declining productivity, there is a strong case for keeping it. The alternative involves bribing the least efficient to quit, with obvious cost and equity implications.

\section{The Regulation of Bargaining}

In a first-best world, a degree of regulation of bargaining is desirable, particularly in order to enforce agreements. In a practical sense, this would always be necessary because of the backdrop of the common law. That said, the extent and nature of the regulations governing bargaining in the Industrial Relations Reform Act are absurd. The legislation not only firmly prescribes the processes but also severely constrains the actual outcomes of agreements. The transactions costs implied by the provisions render agreement-making a serious, lengthy and potentially costly business. Eighteen separate steps are needed to make a Certified Agreement and 21 an Enterprise Flexibility Agreement.

In practice, the provisions governing agreement-making have much less to do with protecting workers than giving a central role to trade unions (whose membership covers less than 30 per cent of private-sector workers). This is done in a number of ways. Suppose a union notifies the Commission of its intention to make a Certified Agreement with a nominated enterprise. The employer is reluctant, foreseeing that little will be gained in terms of enterprise efficiency and a substantial pay increase is being sought. However, the employer is forced to 'bargain in good faith', including attending meetings, divulging information, and so on. Because a 'bargaining period' is in existence, any industrial action is immune from civil liability. The union informs the workers that a short strike will result in a substantial pay increase. A strike takes place, which is very costly to the enterprise. An agreement (possibly including a compulsory unionism clause) is reached, even though the enterprise may have few union members and the employer was unenthusiastic in the first place.

Now imagine a completely non-unionised plant where relations between employer and workers are extremely congenial and productive. Some new working arrangements, which, strictly speaking, contravene award provisions, are negotiated in exchange for a pay rise. The vast majority of the workers are in favour of the agreement. However, when the agreement is taken to the Commission, the relevant union objects because parts of the agreement do not conform with the award. The Commission refuses to ratify the agreement, the workers are disenchanted because 
they do not receive the pay rise, and the union, now aware of this enterprise, begins a recruitment campaign.

These two examples illustrate how the legislation allows unions to become involved in the bargaining process, as well as providing them with a powerful recruitment tool. Arguably, it is principally this agenda, rather than the objective of providing simple, streamlined and stand-alone regulation of bargaining, that is addressed by the legislation.

Finally, it should be noted that a 'no disadvantage' test applies to both Certified Agreements and Enterprise Flexibility Agreements. This states that 'the agreement does not, in relation to their terms and conditions of employment, disadvantage the employees who are covered by the agreement' (p.32). Clearly, the effect of this test is to limit the flexibility of agreements, ensuring that, on balance, employees are at least as well off as under the award. In other words, the routes for enterprise bargaining amount in effect to institutionalised over-award bargaining. There is no scope for an enterprise suffering a slump in product demand, for instance, to seek temporary downward flexibility in an agreement, even though the workers might endorse such a strategy. In theory, award conditions can be traded-off on 'public interest' grounds; in practice, this is likely to be difficult and expensive to achieve. The legislation tempts unions to drip-feed changes at the enterprise level to extract maximum payment for each.

\section{Conclusion}

Many of the adverse economic consequences of the Industrial Relations Reform Act 1993 will be disguised by the economic upswing now under way. For instance, the full impact of the employment termination provisions will not be felt until a slowing down or contraction of output results in widespread job loss. Similarly, the 'no disadvantage' rule is less significant during times of prosperous business conditions. This is not to downplay the economic consequences of the Act; indeed, more than anything, the choice of direction for the legislation represents a missed opportunity to make the labour market more flexible in order to cushion the effects of changes in market conditions.

A very fundamental criticism of the legislation is its inordinate complexity. Whatever the Act's real intentions, regulations should always be simple and minimal. But 'simple' and 'minimal' are not adjectives that anyone would apply to the Industrial Relations Reform Act. The Act is most easily interpreted as an overwhelmingly pro-union package that pretends to protect ordinary workers, but will probably do them more harm than good, especially marginal workers.

Could anything good economically emerge from the Act? Certainly, it emphasises conciliation and the role of bargaining. Depending on the Commission's interpretation of some provisions, there may be some scope for genuine non-union agreements, at least in cases where workers are clearly in favour of an agreement negotiated with management. But this remains to be seen. It is more likely that most employers will shy away from the Enterprise Flexibility Agreement route for 
fear of inviting the unwanted attention of unions. It is not that there is no demand for non-union bargaining; the demand is not satisfied by the restrictive provisions of the Act. Another point is that, for large unionised plants, the Act represents something like the status quo, although the loss of an effective threat via secondary boycott provisions is important to certain companies, particularly those in the resource sector.

As a 'last hurrah' for regulated labour markets in Australia, the legislation certainly covers nearly all the bases. With union membership on the wane, and now below 30 per cent in the private sector, it has been a do-or-die effort by the union movement to engineer such favourable legislation. In the short term, it is likely that unions will be able to use various provisions of the Act to rebuild membership. This will not take the form of winning the hearts and minds of workers or of demonstrating the benefits of membership. It will involve forcing employers to do deals that involve forms of compulsory unionism. Eventually, such a strategy is likely to be self-defeating (Costa, 1992) and the requirements of competitive business will eventually force further legislative change. But policy must always start from somewhere; and in this case, it will be starting from a markedly inferior position than even existed before the Industrial Relations Reform Act 1993.

\section{References}

Commission of the European Communities (CEC) (1993), Employment in Europe 1993, Report of the Directorate-General Employment, Industrial Relations and Social Affairs, Luxembourg.

Costa, M. (1992), 'Mythology, Marketing and Competition: A Heretical View of the Future of Unions', in M. Crosby \& M. Easson (eds), What Should Unions Do?, Pluto Press, Sydney.

Sloan, J. (1993), 'Wage Fixing under Accord Mark VII and the Role of National Wage Principles', Australian Bulletin of Labour 19(3): 218-40. 